This is a self-archived version of an original article. This version may differ from the original in pagination and typographic details.

Author(s): Leinonen, Emilia

Title: Tensions and resilience : the experiences of adult foster-care workers in Finland

Year: 2018

Version: Accepted version (Final draft)

Copyright: @ Policy Press, 2018

Rights: In Copyright

Rights url: http://rightsstatements.org/page/lnC/1.0/?language=en

Please cite the original version:

Leinonen, E. (2018). Tensions and resilience : the experiences of adult foster-care workers in Finland. International Journal of Care and Caring, 2(2), 181-196.

https://doi.org/10.1332/239788218X15224821762868 


\section{Tensions and resilience: the experiences of adult foster-care workers in Finland}

\section{Introduction}

In Finland, the two main objectives of care policy for older people are deinstitutionalisation and ageing in place; the home itself has become the most significant place for long-term care of older people in the past two decades. The principle behind this has been 'honouring the wishes of older people to continue living at home', as well as reducing the cost of publicly funded care services (Ministry of Environment, 2013; Ministry of Social Affairs and Health, 2017). Consequently, there has been a growing interest in innovative housing and care options for older people, particularly those models which incorporate housing and services and also highlight a sense of community (Hynynen, 2015; Jolanki et al, 2017). These new models also change the nature of care work. In this article, I explore a new housing and care service for older people called adult foster care. My purpose is to examine the tensions within foster care work and what helps foster carers to sustain their caring role.

In adult foster care, older people are not cared for by their relatives or friends but by foster carers, who make a 'commission agreement' with a municipality and are remunerated for their work. The scheme is similar to that known in England as shared lives, and in the US as adult placement or adult foster care (Mollica et al, 2008; Brookes and Callaghan, 2013: 87). Research on adult foster care for older people is scarce and insufficient both in Finland and internationally (see however Brookes and Callaghan, 2013; Jolanki et al, 2017; Leinonen, 2017).

In the Nordic context, an adult foster care scheme is a specific variation of care work as, historically, care for older people has been provided either by the formal public sector or informally by family members. Geissler and Pfau-Effinger (2005) have argued that an exclusive focus on these two opposites, 'formal' and 'informal' care, omits recent developments in care work. They call new forms of family-based care work 'semi-formal' care, in which the (family) care relationship is also constructed and regulated by the welfare state. The welfare state legally regulates the care work and supports it financially, without regarding it as formal gainful employment (Frericks et al, 2013). The Finnish Informal Care Allowance, for example, is a semi-formal form of care. Similarly, adult foster care can be positioned somewhere between the formal and informal spheres, and can thus be considered a semi-formal service (Leinonen, 2017) that domesticates care by outsourcing it to semiformal carers, since the older person receiving care moves to a foster carer's home. This profoundly transforms the context of care and of care work. The foster care home becomes a semi-public place 
in which care workers are not formally employed or trained, yet are nevertheless monitored by the public sector.

In this article, findings on adult foster carers' experiences are illustrated in comparison to research on the experiences of both formal care workers and informal carers. The concept of resilience, which here is understood as a holistic psychological phenomenon and as a process of negotiating, managing, or adapting to significant sources of stress (Windle, 2011; Windle and Bennett, 2012; McCann et al, 2015), is used as a tool for analysing the experiences of foster carers. The article is organised as follows: first, the Finnish adult foster care scheme is described in more detail; second, the data and method of analysis are presented. Findings are then presented in relation to three levels of resilience. Finally, the findings are further discussed and embedded in the conceptual framework of resilience.

\section{Adult foster care for older people in Finland}

In Finland, municipalities are responsible for arranging older people's social and health services. Foster care is widely used in child welfare services and in services for disabled people in Finland. Adult foster care has been an option available in housing and care for older people for almost 30 years, but has only recently become a focus of political discussion, legislation and campaigns, partly because of the strong influence of the Finnish Federation of Foster Care Associations (Leinonen, 2017). The current law on foster care came into effect in 2015 and was amended in 2016. The early history of adult foster care is in $19^{\text {th }}$ century 'pauperism', in which the poor and the old were 'sold' to households which would take care of them for a very small amount of money paid by the municipality. Pauperism was widely used in Finland during the 1800s and at the beginning of the 1900s, but in 1922 was forbidden in the Act on Poor Relief, which expanded people's entitlement to poor relief (Ketola, 2008; Markkola, 2008).

Today, adult foster care for older people is a marginal service in Finland, with only 346 older people taken care of in 138 foster care homes in 2016 (The Sotkanet Indicator Bank, 2016). Nevertheless, the Government of Finland places a major emphasis on adult foster care, which is less expensive than traditional institutional care, and aims to increase the number of people living in adult foster care to 1,455 by 2020 (Finnish Government, 2015). The overall goal of this policy is to promote a sense of community and caring within a family, and to decrease older people's feelings of loneliness as the share of people aged over 65 years living alone increases (Statistics Finland, 2015). 
Adult foster care is a form of community-based care in which older people and the foster carer and her/his family live together. According to the Finnish Federation of Foster Care Associations, adult foster care is suitable for older persons who feel insecure and lonely in their own homes, have care needs or a memory disorder but are not yet in need of residential care (Finnish Federation of Foster Care Associations' website; Hakkarainen et al, 2014). At most, an older person in adult foster care pays up to 85 per cent of her/his net income to the municipality. This sum covers everything from meals to linen, cleaning and bathing (but not healthcare). An older person with care needs can be placed in foster care through a care needs assessment completed by a municipal care manager. Usually, but not always, the foster carer and the older person meet before the older person decides whether or not she/he wants to move to the foster care home. The foster carer also has the right to decide whether or not that particular older person can move to her/his foster care home. Older people can be placed in foster care by several different municipalities, so there may be people from up to six municipalities living in one foster care home. The municipality from which the older person comes is responsible for monitoring the quality of foster care (Act 263/2015), and during monitoring visits, care managers pay attention to the foster care home as well as to the wellbeing of the older people and their foster carers.

Foster carers do not need any kind of formal education; motivation, a short training course and suitable personal characteristics, evaluated by the municipality, are sufficient if the carer wishes to care for up to four persons in her/his own home. If two foster carers work in the same household, they can care for up to six persons, although in that case one of the foster carers must have a formal education, for instance in nursing (eg as a practical nurse or registered nurse). The foster carer makes a 'commission agreement' with the municipality, through which the foster carer is not formally employed by the municipality but is paid a monthly fee (which is taxable) and is compensated for their expenses in providing foster care by the municipality. In 2017, the minimum monthly fee per older person was 784 euros and the minimum expenses 411 euros per older person per month. The expenses cover the older person's food and other everyday necessities bought by the foster carer. In addition, carers can get start-up assistance for home alterations and furniture of up to 2,922 euros (Act 263/2015, Ministry of Social Affairs and Health, 2016). Foster carers are entitled to three days' leave per month and to regular health examinations every other year. They are also entitled to pension and are insured in case of occupational injury.

Adult foster care can be arranged as a short-term, part-time or long-term placement. Short-term placements can be used, for example, during informal carers' holidays, while part-time placements 
can be for only a few hours per day. In this article, I am particularly interested in long-term foster care, as this is very different from the above-mentioned foster care models. In long-term foster care the carer and older people share their lives and a home with each other, while in short-term foster care 'one is just visiting', as one interviewee stated.

\section{A tension and resilience perspective}

Resilience as a concept is used in various fields of research, such as in resource management (Berkes et al, 2000), sustainable development (Walker et al, 2004) and the psychological development of children (Masten et al, 1990). However, it has recently gained attention in care and health sciences as well. Providing care for a frail older person is a stressful experience which can wear down the psychological wellbeing of caregivers (Pinquart and Sörensen, 2003). In this article, care is understood as the provision of daily social, psychological, emotional and physical attention for people (Knijn and Kremer, 1997). In care work, the risks vary from physical and emotional strain to threats of violence (Kröger et al, 2009). These tensions within care work are not just single events but more continuous in their nature. In the same way, resilience is by nature a continuous process in which the individual's life, experiences and knowledge intertwine, rather than the occurrence of a single event (Rutter, 2012).

The understanding of resilience has shifted from focusing on the traits of individuals to personenvironment processes (Ungar et al, 2013). Accordingly, in this article, I use Windle's (2011: 163) definition of resilience: 'Resilience is the process of negotiating, managing, or adapting to significant sources of stress or trauma. Assets and resources within the individual, their life and environment facilitate this capacity for adaptation and "bouncing back" in the face of adversity'. Furthermore, Windle (2011) acknowledges that three components must be present for an adult to be resilient: significant adversity, resources to balance the effects of this adversity, and positive adaptation or avoidance of negative outcomes. This means that resilience incorporates an individual's internal and external resource domains in the face of a stressful situation; resilience is thus both a trait and a process (Robertson et al, 2015).

I use the concept of tension to describe the nature of stressful conditions. Like Wetterberg et al (2016), I view the stressors as counterparts to resources of resilience, as 'demands that a person does not automatically know how to respond, which creates a state of tension'. To be resilient does not mean one has never encountered an adversity or a traumatic situation. In fact, it means that after a traumatic event one can 'bounce back' and become more resilient in similar situations. In addition, one might 
struggle in one area, such as in financial wellbeing, but be highly socially resilient (Wild et al, 2011). In the same way, what is considered to be a risk or a stress factor for some people in certain situations can be harmless for others (Wild et al, 2013).

Windle (2011) has further argued that resilience factors are present or absent on three different resource levels: on the societal, communal, or individual levels, and that these levels overlap and intertwine with each other. Societal level resources include social policy, social support services, neighbourhood, economy, and health and social care services. Community level resources include social support, social cohesion, social participation, and housing, whereas the individual level includes psychological resources, biological resources, gender, age, health behaviour and material resources.

The concept of resilience was heavily criticised by Evans and Reid (2014) in their book 'Resilient Life: The Art of Living Dangerously'. They argue that the concept of security has been 'shod' by liberalism as it embraces the new ideal of resilience as the fundamental property which individuals must possess. They contend that insecurity has become the new normal and that resilience places the burden of the crisis on the shoulders of the individual (Evans and Reid, 2014). With this criticism in mind, the intention of this article is not to focus merely on resilience, the positive side of foster care, but to map and make visible the different adversities carers face in their work, and the ways carers can become, and can be helped to become, more resilient. In addition, it is important to note that being resilient does not necessary mean superior functioning or flourishing, it is as much 'doing OK' (Windle, 2011; Windle and Bennett, 2012).

As stated above, resilience as a concept bears a lot of weight, but can capture the specific nature of tackling various tensions in a better way than a mere 'coping strategy' would, because resilience also takes into account the carers' external resources (e.g. social policy and social support from the community), not just their internal resources (Rutter, 2012). The connectivity of internal and external resources is a pivotal part of building resilience, since tensions and resilience do not happen in a vacuum. This connectivity also guides the thematic analysis of this article, presented next.

\section{Interview data and thematic analysis}

This article is based on 12 thematic interviews with adult foster carers undertaken between October 2016 and May 2017. The themes of the interviews focused on foster carers' everyday lives and their expectations of, and experiences and difficulties in, their care work. Foster carers were recruited to 
the study from different regions of Finland through regional service managers who made the initial contact with carers to enquire about their interest in participating in an interview. If the carer was interested, service managers either gave the carer's contact details to the researcher or the carers themselves contacted the researcher via email or phone. The recruitment was limited to those carers who provided long-term foster care, although one carer interviewed, Ritva, had provided long-term foster care in the past but had recently moved and decided to provide only short-term foster care. She was also the only interviewee who provided care by herself; all others had either their spouse, a relative or a friend working with them. Kirsi and Juha (spouses), Anneli and Matti (spouses) and Anna and Marja (mother and daughter) were interviewed at the same time. Anna was already retired from foster care work but was still substituting for Marja during her holidays.

The data collection took place in carers' homes. The thematic audio-recorded interviews lasted from 47 to 155 minutes, being 105 minutes on average. The dataset consists of 159 transcribed pages. All participants gave independent informed consent and their names were changed to pseudonyms for anonymity. Of the 12 participants, 10 were women. The participants were aged between 33 and 68 years. Seven had a formal education in the social and health care sector, others were retired or had worked previously in teaching or the business sector. Table 1 summarises some of the key characteristics of the interviewees, and indicates each participant's name, age, education or work experience, the number of older people living, long-term, in the foster care home, how many years they had worked as a foster carer, and their income per month (after taxes). In addition to long-term residents, interviewees had short- and part-time residents, which explains the differences in their incomes. On average, and after taxes, a foster carer gets around 1000 euros per month per older person living long-term in a foster care home. This amount is composed of both the care fee and expenses. Marja, Saara and Johanna shared the net income with their partner or friend they were working with.

Table 1. Participants' characteristics $(\mathrm{m}=$ male, $\mathrm{f}=$ female $)$

\begin{tabular}{|l|c|l|c|c|c|}
\hline Name & Age & $\begin{array}{l}\text { Education/Work } \\
\text { experience }\end{array}$ & $\begin{array}{l}\text { Number of older } \\
\text { people living long- } \\
\text { termly in the foster } \\
\text { care home }\end{array}$ & $\begin{array}{l}\text { Years as foster } \\
\text { carer }\end{array}$ & $\begin{array}{l}\text { Income per } \\
\text { month (€, after } \\
\text { taxes) }\end{array}$ \\
\hline Kirsi (f) & 64 & practical nurse & 3 & 6 & 3980 \\
\hline Juha (m) & 64 & retired & 2 & 1 & 2500 \\
\hline Marja (f) & 45 & practical nurse & 6 & 6 & 6000 \\
\hline Anna (f) & 68 & practical nurse & 3 & 3 & 3500 \\
\hline Ritva (f) & 52 & practical nurse & 4 & 2 & 3100 \\
\hline Irene (f) & 59 & $\begin{array}{c}\text { practical nurse, no } \\
\text { education }\end{array}$ & 4 & & \\
\hline
\end{tabular}




\begin{tabular}{|l|c|c|c|c|c|}
\hline Saara (f) & 33 & registered nurse & 6 & 2 & 8200 \\
\hline Anneli (f) & 52 & catering entrepreneur & 1 & 4 & 2500 \\
\hline Matti (m) & 58 & storeman & 0 & 4 & n.a. \\
\hline $\begin{array}{l}\text { Johanna } \\
\text { (f) }\end{array}$ & n.a. & $\begin{array}{c}\text { Bachelor of Social } \\
\text { Services and Health } \\
\text { Care }\end{array}$ & 5 & $<1$ & 3600 \\
\hline Sisko (f) & 52 & teacher & 2 & $<1$ & 5800 \\
\hline Toini (f) & 64 & registered nurse & 2 & $<2$ & \\
\hline
\end{tabular}

\section{Thematic analysis}

In this article, I focus on two questions: 'what kind of problems do foster carers face in their work?', and 'how do they cope with these problems?' These questions created the two main themes of this article, i.e. tensions carers face in their work and resilience. I use the guidelines for thematic analysis developed by Braun and Clarke (2006) to identify sub-themes within these main themes. Braun and Clarke (2006: 87) divide thematic analysis into six phases: 1. familiarising yourself with your data, 2. generating initial codes, 3. searching for themes, 4. reviewing themes, 5. defining and naming themes and, 6. producing the report. I was very familiar with the data as I was the sole interviewer and had transcribed three of the interviews. Along with re-reading, I was also beginning to generate initial codes from the data, such as 'obstacle', 'care work', 'free time' and 'support'. The next step was to search for themes, in this case for sub-themes. The interviewees were asked about the rewarding aspects of foster care, on the one hand, and the stressful aspects, on the other. The interviewees brought up things such as their motivation, professionalism, social resources, financial situation, lack of information, and lack of holidays.

In this article, I employ all three levels of resilience, that is, societal, communal, and individual, and include the following resources of resilience which corresponded to the themes found in the data: social policy, social support services, health and social services (society); social support and social participation (community); and psychological and material resources (individual). After reviewing the sub-themes, the following sub-themes connected to the main theme of tensions were identified (and named): 1) caring as emotionally draining (individual level); 2) adverse effects on social relationships (communal level); and 3) trust (societal level). The first sub-theme was composed of finance and violence, the second sub-theme of friendship, lack of substitutes and lack of holidays, and the third sub-theme of information and attitudes. The resilience main theme included the following sub-themes: caring as purposeful (individual level) and social resources (communal and societal level). The sixth phase, producing the final analysis, was undertaken in relation to the research 
questions and the theoretical framework of resilience. The analysis focused on combining the levels of resilience and the sub-themes mentioned above.

\section{Findings}

\section{Tensions foster carers face in their work}

\section{Individual level: Caring as emotionally draining}

On the individual level, foster care work is physically, but especially emotionally draining. The interviewees had faced various kinds of adversities, ranging from fears of financial security to physical violence and sexual harassment, all of which were harmful to the foster carers' mental wellbeing and created a state of continuous tension in their lives. According to previous research, care workers in Finland feel more inadequate, are threatened more often by physical violence, and have higher physical and mental strain than their colleagues in other Nordic countries (Kröger et al, 2009). Three interviewees stated they had experienced physical violence by older people they were caring for. In one of the violence cases, the foster carer was hit with a walking stick when she was trying to stop an older person from going out with only her socks on. This incident was reported to the municipal officials, whose decision was that the foster carer should have respected the older person's self-determination and let her to go out; the decision diminished the trust between the foster carer and the municipality and resulted in the foster carer's reluctance to take new inhabitants from that particular municipality. In addition, one interviewee said that he had been sexually harassed by one older person, but that the matter had been solved within the family and was never disclosed to the officials.

Regarding material resources, the care fee was considered insufficient by all foster carers, since in practice they were 'on duty' 24 hours per day. Some had earned more in their previous work. They also felt it was insufficient because of the major investments they had made, e.g. buying a suitable house and taking out a loan for it. In addition, a few foster carers had a separate house or apartment where they went in their free time. Although most municipalities pay a care fee in line with the Law on Foster Care and regional general directives, some foster carers had difficulty getting the correct care fee. Sometimes the fee was paid late, or even not at all. Interviewees in one region described this as 'a constant battle' in which they had personally to check that they received the fee they were entitled to. Furthermore, almost all foster carers were subjected to talk of jealousy, whether connected 
to the amount of money they were getting or in general to the 'easiness' of the work they were doing. As Matti describes:

There is also another kind of criticism, behind our backs of course. People say that everything is so easy for us, that we get tons of money off those grannies, and all we need to do is to chat with them and brew coffee. I have said many times, 'Come here for a couple of days and see what we are doing here'. (Matti)

\section{Communal level: Adverse effects on social relationships}

Informal carers often lack social contacts and may experience feelings of loneliness (Brodaty and Donkin, 2009). Also, on a communal level, foster care work seems to have very adverse effects on social relationships and on the foster carers' opportunity to have hobbies or holidays. The work is highly restrictive as the foster carer is constantly responsible for the older people living with her/him. For many, the biggest surprise was how ill the older persons with them were: 'We thought we could visit markets and cultural events, but no, we cannot go anywhere as they are so ill and have serious memory disorders' (Johanna). This had a major effect on opportunities to engage in any activities with the older people which required active participation, such as cooking together. It also affected the attitudes of the friends of the foster carers, as they did not want to visit any more.

There is no seeing friends, sometimes I leave to see somebody after 9 pm when I get the grannies to sleep, but I'd say that has happened twice in one and half years. All my friends vanish around me, also because of jealousy, we know that a Finnish person should not try, or at least should not have, success. (Toini)

The main reason for being unable to go on holiday was the lack of suitable substitutes or substitute care. Although the municipality is responsible for arranging substitutes for foster carers during their days off, in practice this did not always happen, even when the foster carer was on sick leave. In fact, most of the interviewees said that they had to find their substitutes themselves:

You know, in the commission agreement it states that it is the municipality's responsibility to arrange a substitute. But in practice it was not so: if I did not find anyone from among my friends or fellow students or anyone trustworthy to whom I could leave these people and my home, it meant they (the older people) went to some short-term place. It was the only thing the municipality could arrange. (Ritva)

The interviewees were divided in how they viewed the importance of holidays and free time. Some were very strict in keeping all holidays they have earned, and some kept extra days off too, although it might mean they got less money. For some, holidays were not so important; for example, one carer 
had not been on a holiday for two years as she and her husband regarded all the holiday arrangements, such as finding substitutes, giving instructions, and packing, as too exhausting. Some couples arranged their free time so they were on a holiday in turns, in order to be able to have a longer holiday period together during the summer.

\section{Societal level: Lack of openness}

On a societal level, foster carers faced problems regarding the lack of adequate information on older people moving into a foster care home, negative attitudes and lack of support. Previous studies consistently report unmet needs among informal carers, particularly regarding information (Bee et al, 2009; Washington et al, 2011). The unmet need for information is present in foster care work too, as some interviewees reported that the information they received about a new older person to be placed in their foster care home was nothing more than a list of their medication. In other words, foster carers did not know anything about the older person before she/he arrived in the foster care home.

Anna: When they (older people) come here, many of them have only a bundle of prescriptions in their hands; sometimes not even that, as the prescriptions can be in the home nursing agency. And then you just have to check those prescriptions, as you do not really know what kind of illnesses they have.

Interviewer: So, you do not get any information about that (the illnesses)?

Anna: No. Just a list of medication. We divide the medicines according to that. Then we are just guessing that maybe this person has this or that illness, since they are getting this or that medicine. (laughs)

Connected to the lack of information, there was also a lack of support from the municipality. In informal care, availability and acceptance of formal support is associated with a decreased burden of care work and an increased sense of well-being (Cherry et al, 2013). The ideal of the foster care is that older people could live in a foster care home for the rest of their lives. Death is therefore one inevitable part of the care. According to the interviewees, after a death of an older person, municipalities did not necessarily offer any support services to the foster carer. For instance, Johanna, who said that she did not usually need support from the municipality, explained that after a long and intensive end-of-life care period she was so tired that support was needed. But she did not get any.

Alarmingly, foster carers felt that municipal officers had negative attitudes towards foster care, which made the care work harder. Many foster carers felt they were not appreciated by the older person's relatives or by social workers. Some foster carers felt they were not regarded as care workers, and 
therefore were not treated as equal to other carer workers. A few interviewees stated that the officers in charge of social care services did not want to share any knowledge about adult foster care with their subordinates because they were not willing to offer foster care as an option for their service users. This resulted in cases where care managers were not even aware of foster care when foster carers contacted them.

\section{Resilience of foster carers}

\section{Individual level: Caring as purposeful}

Although foster carers were subjected to various adversities in their work, such as violence, financial problems, and lack of holidays and support from the municipality, all had their own coping strategies and external resources which made them resilient and, overall, content with their work. In all cases, foster carers showed a high degree of resilience towards being a care provider, and 'being significant in their own eyes' (Wennerberg et al, 2016). As many of the interviewees had work experience in hospitals, residential care or home care, they felt the largest difference between professional care work and adult foster care work was the unhurried pace of living and giving care. Caring was seen as purposeful and satisfying, especially for those who felt they, and their work, were appreciated by the older people and by their relatives. To be able to give time to older people, to do things together and to be one's own boss were the key factors which made the care work purposeful. As Ritva says:

The most rewarding thing in this work is to see the progress and rehabilitation of the older people. And of course, the gratitude is also rewarding. When someone says every night that 'you are so kind that you take care of me' or 'how sweet you are' or 'thank you for looking after me', it is very rewarding. (Ritva)

Many interviewees criticised their previous workplaces and care policy in Finland. For instance, Maria and Anna were very concerned about the ageing in place policy, as they had seen many malnourished people coming into foster care from their homes - despite home care services, one older person weighed only 37 kilograms when she was placed in foster care. None of the foster carers, who had worked in hospitals, residential care or home care, wanted to go back to their previous work:

In no way would I go back to the ordinary [care work], I think I would change the line of work then. After all, one reason, one of the many reasons, why I started this was the fact that I 'went numb' in my work, the pressure, the work pace, the responsibility, the awful and constant performing... and then, the person there, the 
person is almost a secondary thing there. You are just tapping your computer away there. To be frank, in an ugly way, it is almost quasi-care work there versus what I think care work should be, to really take care of a person. (Saara)

Those foster carers who had a formal education in healthcare regarded themselves as professionals; their experience and knowledge facilitated the management of the illnesses, as their problem-solving skills were, to their mind, better than those of (for example) foster carers who were not educated as a nurse. However, when asked about what kind of attributes a good foster carer possesses, three words came up most frequently: humour, empathy, and genuineness - not education. Compared with formal care work, in which feelings of guilt and inadequacy may appear when there is not enough time to provide care caused by the work environment (Kröger et al, 2009; Häggström et al, 2010), foster carers were very proud of their work and of providing good care and a home for the older people living with them. A few carers even viewed themselves, their partners, their children, and the older people as a family, in which the carer and care receiver roles were almost non-existent, compared with care institutions. The professional boundaries that are important in formal care work (Ablett and Jones, 2007) were absent in foster care work. As Sisko describes:

I have seen many places which call themselves home-like, these little care institutions found everywhere nowadays. Although they are home-like they are not like homes. In my opinion, there is [in a care institution] always the care worker and the care receiver, not like we are in our family, we are all people here. (---) It is almost a relief that, although I have an education, I have to 'take it off'; even though I know about things and about care work, I do not have to underline that I am a nurse, and that I know everything, and that I am somehow above you. (Sisko)

Previous studies have shown that caregivers with higher self-efficacy and personal mastery are more resilient (Fortinsky et al, 2002; Harmell et al, 2011). According to the data, the ability to accept and manage the illness, eg a memory disorder and its symptoms, was significant in decreasing the mental strain caused by the care work (see also Cherry et al, 2013). Here the adaptation process is crucial. As Juha expresses it:

About the stress factors, firstly you have to make clear to yourself that when you start this job, you cannot walk on water. I mean you cannot heal the illnesses. Inevitably those illnesses will progress, no matter what you do, and if you do not do this job, somebody else will. You cannot blame yourself for everything. (Juha) 
As Rutter and Rutter (1993) have pointed out, resilience is strongly influenced by social relationships. Social support can enhance resilience and is therefore a valuable and protective resource of informal carers (Wilks and Croom, 2008; Brodaty and Donkin, 2009; Donnellan et al, 2015). Similarly, foster carers got help and support from their social relationships, the most important support coming from their family and friends. The availability of support and satisfaction with support are more important to the wellbeing of caregivers than the actual size of the support network (Roth et al, 2005). Hence, the quality of support is significant. As the data indicates, couples in which both partners were working as foster carers got a lot of support from each other, which compensated for the lack of support from others. According to the interviews, a good division of labour was essential in achieving a balanced life:

\begin{abstract}
Absolutely 100 per cent team work with my husband. It is the foundation and structure of our everyday life, completely. We both know, without saying, what should happen at a certain time of day. And you know what the other one is feeling, as, of course, there are days when you just cannot do this work anymore, and then you can share it, talk it through, and the other one knows exactly the situation and all the things behind it. (Saara)
\end{abstract}

Also, peer support can directly improve the wellbeing of carers by decreasing feelings of isolation (Charlesworth et al, 2011; Dennis, 2003). Peer support was very important for many foster carers, although opportunities to meet face-to-face with other foster carers were limited, again due to the restrictive nature of the work. A new guideline in Finland recommends that every new foster carer should have a named mentor who can guide, give advice, and be the person from whom the foster carer can get peer support (Finnish Federation of Foster Care Associations 2017). However, of the interviewees, only Anneli and Matti had a mentor. Foster carers met other foster carers mainly during regional or nationwide training days organised a few times per year. It is important to keep in mind that resilience does not happen in a vacuum. Support from family, friends and the municipality are an essential part of the process, since individuals may fail to become resilient if the community does not facilitate opportunities to adapt (Ungar, 2012).

\title{
Discussion
}

The purpose of this article is to examine the tensions which foster carers face in their work, and to understand what helps them to sustain their caring role. The concept of resilience, the dynamic 
process in which an individual's traits, experiences, and communal and societal resources intertwine (Windle, 2011; Rutter, 2012) has been used as a framework for the analysis. One of the most interesting results is that foster carers are able to manage and adapt to tension but have few resources to negotiate better work conditions with the municipalities. The results indicate that foster carers face many different tensions in their work; work which is, at the same time, both their working life and their personal life. The tensions embedded in foster care work seem to be more similar to informal care than to formal care: all interviewees had experienced some problems with the municipalities, they all felt the care fee was inadequate, and they all felt their social network was narrower than before. On the one hand, these issues were linked especially to the material resources of an individual, visible as a lack of money and of time. The actual causes of these tensions, however, came more from outside the foster care home, mainly from the municipalities, that is, from the societal level.

The results indicate that foster care work itself actually generated resistance and empowered foster carers to see themselves as professionals in their work. On the individual level, their humour, compassion and inner need to help others gave them ways of coping with difficult issues, such as the lack of appreciation. On the communal level, their social support networks made them resilient, whether the support came from their family, relatives, spouse, friends, peers, hobbies or from the work itself. This result is consistent with previous resilience research (Wilks and Croom, 2008; Donnellan et al, 2015).

The continuousness of stress, worries and feelings of social isolation are major risk factors which can hamper the positive effects of foster care work. Foster carers are indeed in need of constant support and commitment from the municipality and may otherwise experience social isolation through lack of personal time and opportunities to socialise and share experiences. About half the interviewees had good and trusting relationships with the municipalities they worked with. Here the word 'with' is pivotal, since openness, trustworthiness and working social support services made the foster carers feel they were not working alone; rather, it made them feel that they were an important part of the municipality's care services, and as appreciated as other care workers.

The semi-formal nature of the foster care work is visible in the relationship between foster carer and the municipality. On one hand, the privacy of a foster care home may hide the problems of the care work; on the other, foster carers may be less protected when, for example, facing violence. It is rather surprising, however, that foster carers had so many problems with the municipalities. One might assume that although foster carers are not formally employed by the municipalities, they would get 
more support from their 'semi-employer'. Without support, informal or formal, foster carers can feel emotionally burdened. As Ungar (2011) argues, the context - in this case the municipality and its services - plays a crucial role in facilitating resilience, and may in fact be where the resources and efforts should first be concentrated. If the support system works, resilience at the individual level is easier to achieve. That is why it is essential for all foster carers to have access to peer support on a regular basis. This could be achieved, for example, by widening mentoring services from new foster carers to all.

Another key issue is to ensure that foster carers are able to have both short breaks during the day, for example by recruiting volunteers, and longer holiday periods. If the Government's target of multiplying the number of older people living in foster care homes is to be reached, specific attention needs to be given to foster carers' wellbeing. Regular health examinations are a good start, but in addition, a uniform nationwide directive needs to be established to minimise regional differences in the care fee, social support services, and (especially) the attitudes of officers, social workers and care managers. One way of ensuring this could be to look at current practices from the perspective of resilience.

With a small sample size, generalisations cannot be drawn from the data presented here. Nevertheless, this study gives a first glimpse of the work of adult foster carers, and of what it takes and what it gives. For further study, more research is needed on the foster care for older people in general, on the relationship between the carer and the older person in particular, and, overall, on older people living in foster care homes. Has their quality of life improved since moving into the foster care home? What kind of effects has it had on the older person's social relationships, on their opportunities to participate, and on their feelings of loneliness? Furthermore, comparative international research would be important for understanding the role and potential of adult foster care in different social policy contexts.

\section{Acknowledgements}

I am grateful for all those foster carers who were willing to share their experiences with me. Warm thanks to my editors, reviewers and supervisors - Professor Teppo Kröger and Academy researcher Mia Tammelin - for their useful insights and comments. This study is conducted at the University of Jyväskylä as part of the ASUVA project (New alternatives for living and housing, funded by the Prime Minister's Office). The study is also a part of Linked Ageing: Interdependencies in Housing 
and Care in the Course of Later Life (LinkAGE) and the Centre of Excellence in Research on Ageing and Care (CoE AgeCare) funded by the Academy of Finland (312303).

\section{References}

Ablett, J. R. and Jones, R. S. P. (2007) Resilience and well-being in palliative care staff: a qualitative study of hospice nurses' experience of work, Psycho-Oncology, 16: 733-40.

Bee, P.E., Barnes, P. and Luker, K. (2009) A systematic review of informal caregivers' needs in providing home-based end-of-life care to people with cancer, Journal of Clinical Nursing, 18: 1379-93.

Berkes, F., Folke, C. and Colding, J. (2000) Linking social and ecological systems: Management practices and social mechanisms for building resilience, Cambridge: Cambridge University Press.

Braun, V. and Clarke, V. (2006) Using thematic analysis in psychology, Qualitative Research in Psychology, 3(2): 77-101.

Brodaty, H., and Donkin, M. (2009) Family caregivers of people with dementia, Dialogues in Clinical Neuroscience, 11(2): 217-28.

Brookes, N. and Callaghan, L. (2013) What next for Shared Lives? Family-based support as a potential option for older people, Journal of Care Services Management, 7(3): 87-94.

Charlesworth G., Burnell, K., Beecham, J., Hoare, Z., Hoe, J., Wenborn, J., Knapp, M., Russell, I., Woods, B., and Orrell, M. (2011) Peer support for family carers of people with dementia, alone or in combination with group reminiscence in a factorial design: study protocol for a randomised controlled trial, Trials 12(205).

Cherry, M.G., Salmon, P., Dickson, J.M., Powell, D., Sikdkar, S. and Ablett, J. (2013) Factors influencing the resilience of carers of individuals with dementia, Reviews in Clinical Gerontology 23: 251-266.

Dennis, C. (2003) Peer support within a health care context: A concept analysis, International Journal of Nursing Studies 40(3): 321-32.

Donnellan, W., Bennett, K. and Soulsby, L. (2015) What are the factors that facilitate or hinder resilience in older spousal dementia carers? A qualitative study, Aging \& Mental Health 19(10): 932-39.

Evans, B. and Reid, J. (2014) Resilient life: The art of living dangerously, Cambridge: Polity Press.

Finnish Federation of Foster Care Associations (2017), https://www.perhehoitoliitto.fi/perhehoito/ikaihmiset . 
Finnish Government (2015) Finland, land of solutions. Programme of Prime Minister Sipilä's Government, http://valtioneuvosto.fi/documents/10184/1427398/Ratkaisujen+Suomi EN YHDISTETTY netti.p df/8d2e1a66-e24a-4073-8303-ee3127fbfcac .

Fortinsky, R., Kercher, K. and Burant, C. (2002) Measurement and correlates of family caregiver self-efficacy for managing dementia, Aging \& Mental Health, 6(2): 153-60.

Frericks, P., Jensen, P. and Pfau-Effinger, B. (2013) Social rights and employment rights related to family care: Family care regimes in Europe, Journal of Aging Studies 29: 66-77.

Geissler, B. and Pfau-Effinger, B. (2005) 'Change in European care arrangements', in PfauEffinger, B. and Geissler, B. (eds) Care and social integration in European societies, Bristol: Policy Press.

Hakkarainen, P., Kuukkanen, M. and Piispanen, H. (2014) Perhehoidon tietopaketti (Information package of adult foster care), Jyväskylä: Perhehoitoliitto ry.

Harmell, A., Chattillion, E., Roepke, S. and Mausbach, B. (2011) A review of the psychobiology of dementia caregiving: A focus on resilience factors, Current Psychiatry Reports 13(3): 219-24.

Hynynen, R. (2015) Palvelualueen ja ikäystävällisen asuinalueen kehittäminen (The development of service area and age friendly neighbourhood') Reports of the Ministry of Environment, 5/2015.

Häggström, E., Mamhidir, A.-G. and Kihlgren, A. (2010) Caregivers' strong commitment to their relationship with older people, International Journal of Nursing Practice, 16: 99-105.

Jolanki, O., Leinonen, E., Rajaniemi, J., Rappe, E., Räsänen, T., Teittinen, O. and Topo, P. (2017) Asumisen yhteisöllisyys ja hyvä vanhuus (The sense of community in housing and good old age'). Government's analysis, assessment, and research publication series 47/2017.

Ketola, J. (2008) Perhehoito. Tekemisen ja tukemisen arvoista työtä (Foster care. Work worthy of doing and supporting), Jyväskylä: PS-Kustannus.

Knijn, T. and Kremer. M. (1997) Gender and the caring dimension of the welfare states: Towards inclusive citizenship', Social Politics, 4(3): 328-61.

Kröger, T., Leinonen, A. and Vuorensyrjä, M. (2009) Hoivan tekijät. Suomalainen hoivatyö pohjoismaisessa tarkastelussa (Doing care: Finnish care work in Nordic comparison) Publication series of social work 6, University of Jyväskylä.

L263/2015 Act on adult foster care. Available at http://www.finlex.fi/fi/laki/alkup/2015/20150263

Leinonen, E. (2017) 'Jotain uutta, jotain vanhaa, jotain lainattua - ikääntyneiden perhehoito Suomessa' (Something new, something old, something borrowed - adult foster care for older people in Finland) Gerontologia 31(3), 210-24.

Markkola, P. (2008) Welfare provision in Finland in the 19th and early 20th Centuries, History in Focus (14). 
Masten, A., Best, K., and Garmezy, N. (1990) Resilience and development: Contributions from the study of children who overcome adversity, Development and Psychopathology, 2(4): 425-44.

McCann, T., Bamberg, J. and McCann, F. (2015) Family carers' experience of caring for an older parent with severe and persistent mental illness, International Journal of Mental Health Nursing, 24: 203-12.

Ministry of Environment (2013) Housing development programme for older population for 20132017. http://www.ym.fi/en-

US/Housing/Programmes_and_strategies/The_development_programme_for_housing_for_elderly_ people

Ministry of Social Affairs and Health (2016) Perhehoidon palkkiot ja korvaukset (Care fees and compensation of expenses of adult foster care) Available at http://stm.fi/artikkeli/lasset_publisher/kuntainfo-perhehoidon-palkkiot-ja-korvaukset-vuonna-2017

Ministry of Social Affairs and Health (2017) Quality recommendation to guarantee a good quality of life and improved services for older persons. Available at http://julkaisut.valtioneuvosto.fi/handle/10024/160688

Mollica, R., Booth, M., Gray, C. and Sims-Kastelein, K. (2008) Adult foster care: a resource for older adults, http://www.nashp.org/sites/default/files/AFC_resource.pdf .

Pinquart, M. and Sörensen, S. (2003) Differences between caregivers and non-caregivers in psychological health and physical health: A meta-analysis', Psychology and Aging 18(2): 250-67.

Robertson, I., Cooper, G., Sarkar, M. and Curran T. (2015) Resilience training in the workplace from 2003 to 2014: A systematic review, Journal of Occupational and Organizational Psychology 88: 533-62.

Roth, D. L., Clay, O. J., Madan, A., Mittelman, M. S., and Haley, W. E. (2005) Changes in social support as mediators of the impact of a psychosocial intervention for spouse caregivers of persons with Alzheimer's disease, Psychology and Aging, 20(4): 634-44.

Rutter, M., and Rutter, M. (1993) Developing minds: Challenge and continuity across the lifespan, New York: Basic Books.

Rutter, M. (2012) Resilience: Causal pathways and social ecology, in M. Ungar (ed), The social ecology of resilience: A handbook of theory and practice. New York: Springer.

The Sotkanet Indicator Bank (2016) Perhehoidossa olleet vanhukset 31.12., kunnan kustantamat palvelut. Vanhusten perhehoitokotien lukumäärä 31.12., kunnan kustantamat palvelut (Older people in adult foster care 31.12. funded by the municipalities. The number of adult foster care homes

31.12. funded by the municipalities)

https://www.sotkanet.fi/sotkanet/fi/taulukko/?indicator=sy7Njc8HAA==\&region=s07MBAA=\&yea $\underline{\mathrm{r}=\mathrm{sy} 4 \mathrm{rtzbS} 0 \mathrm{zUEAA}==\& \mathrm{gender}=\mathrm{t} \& \mathrm{abs}=\mathrm{f} \& \text { color }=\mathrm{f}}$ 
Statistics Finland (2015) Dwellings and housing conditions. Helsinki: Statistics Finland. http://tilastokeskus.fi/til/asas/2015/asas_2015_2016-05-24_tie_001_fi.html.

Ungar, M. (2012) Social ecologies and their contribution to resilience, in M. Ungar (ed) The social ecology of resilience: A handbook of theory and practice, New York: Springer, pp. 13-32.

Ungar, M., Ghazinour, M. and Richter, J. (2013) Annual research review: What is resilience within the social ecology of human development?, Journal of Child Psychology and Psychiatry, 54: 34866.

Walker, B., Holling, C.S., Carpenter, S.R., and Kinzig, A. (2004) Resilience, adaptability and transformability in social-ecological systems, Ecology and Society 9(2): 5.

Washington, K., Meadows, S., Elliot, S. and Koopman, R. (2011) Information needs of informal caregivers of older adults with chronic health conditions, Patient Education and Counselling, 83(1): 37-44.

Wennerberg, M., Eriksson, M., Danielson, E. and Lundgren, S. (2016) Unravelling Swedish informal caregivers' generalised resistance resources', Scandinavian Journal of Caring Sciences, 30: $602-13$.

Wild, K., Wiles, J., and Allen, R. (2011) Resilience: thoughts on the value of the concept for critical gerontology Ageing and Society, 33: 137-58.

Wilks, S. and Croom, B. (2008) Perceived stress and resilience in Alzheimer's disease caregivers: Testing moderation and mediation models of social support, Aging \& Mental Health 12(3): 357-65.

Windle, G. (2011) What is resilience? A review and concept analysis, Reviews in Clinical Gerontology, 21: 152-69.

Windle, G. and Bennett, K. (2012) Caring relationships: how to promote resilience in challenging times', in M. Ungar (ed), The social ecology of resilience: A handbook of theory and practice. New York: Springer, pp. 219-31. 